\title{
An Investigation Into The Comparisons Of Exhaust Emissions Through Catalytic Converters Installed On A Kia Sportage Lx (Exhaust System)
}

\author{
Isaac Tekper ${ }^{1}$, Joseph Kwame Lewballah ${ }^{1}$, James Kwasi Quaisie ${ }^{3}$, Fred Joseph Komla Adzabe ${ }^{1}$, Emmanuel \\ Yeboah Osei $^{1}$, Emmanue $^{1}$ Asamoah $^{3}$, Philip Baidoo ${ }^{2}$, Andrews Danquah ${ }^{1}$ \\ ${ }^{1}$ Dept. of Mechanical Engineering, Kumasi Technical University, Kumasi, 00233, Ghana \\ ${ }^{2}$ Faculty of Technology, University of Education Winneba, Kumasi, 00233, Ghana \\ ${ }^{3}$ School of Mechanical Engineering, Jiangsu University, Zhenjiang, Jiangsu 212013, China
}

DOI: 10.29322/IJSRP.10.03.2020.p9908

http://dx.doi.org/10.29322/IJSRP.10.03.2020.p9908

\begin{abstract}
This paper presents a study on the comparisons of the $\mathrm{HC}$ and $\mathrm{CO}$ emission levels on exhaust gases that expels through an existing home used (imported) car converter, a refurbished catalytic converter with a new honeycomb. The performance of a home used catalytic converter, refurb damaged catalytic converters by replacing the worn-out catalyst elements with imported ceramic honeycomb catalysts and compare the performance of the used catalytic converter to that of refurbished and two other locally developed converter of a Kia Sportage LX exhaust system were studied. The experimental results indicated that the refurbished catalytic converter with welded test and ecoliquid wash, produced lower emission than the home used, locally developed converter 1 (Suame Magazine) and locally developed converter 2 (Abossey Okai). For the locally made ones, the welded part of the case was not uniform therefore creating space for the exhaust gas to escape without proper filtration. The result also indicated that $\mathrm{HC}$ emission of $60.0 \mathrm{ppm}$ was recorded for the refurbished converter at an initial speed of $10.0 \mathrm{~km} / \mathrm{hr}$ which is relatively lower than the $\mathrm{HC}$ emission recorded for the home used (65.8 ppm) catalytic converter. In addition, the refurbished type achieves a significant $H C$ emission reduction of $5.8 \mathrm{ppm}$ when compared with the other types. The $\mathrm{CO}$ emission, the refurbished type had a reduction of $0.01 \% \mathrm{Vol}$ when compare with the homeused converter at varying speeds. Furthermore, the maximum test speed of $60 \mathrm{~km} / \mathrm{hr}$ both the home-used and refurbished converters recorded the highest amount of $H C(70.9 \mathrm{ppm}, 63 \mathrm{ppm})$ and $C O$ ( $2.52 \% \mathrm{Vol}, 2.42 \% \mathrm{Vol})$ from the engine exhaust respectively. The refurbished converter yielded about $3.41 \%$ reduction in $\mathrm{HC}$ emission and $7.92 \% \mathrm{CO}$ emission which is better as compared to the Locally Developed converter 1 (Magazine). Again, the refurbished converter attained $4.39 \%$ reduction in $\mathrm{HC}$ emission when compared to the Locally Developed converter 2 (Abossey Okai) at idling speed.
\end{abstract}

Index Terms- hydrocarbon, carbon monoxide, refurbished, converters, catalyst.

\section{INTRODUCTION}

Tn a diesel engine, the engine condition is different from sparkignition engines, because power is directly controlled by the fuel supply, not by controlling the air supply [1]. So when running at low power, there is enough oxygen present to burn the fuel, and diesel engines only create a large amount of carbon monoxide when running under load. Diesel exhaust has been found to contain many toxic air contaminants [2]. Lean-burning properties of diesel engine combined with a high temperature and pressure of the combustion process result in significant production of nitrogen oxides and provide a unique challenge in the reduction of these compounds $[\underline{3}, \underline{4}]$.

\subsection{Catalytic converter}

A catalytic converter (colloquially, " cat ' or "catcon ") is a device used to reduce the toxicity of emissions from an internal combustion engine. A catalytic converter provides an environment for a chemical reaction wherein toxic combustion by-products are converted to less toxic substances (Fig. 1).

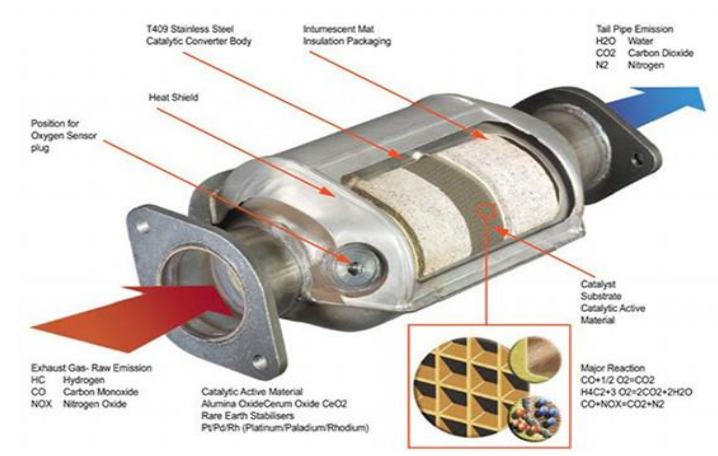

Fig. 1. Three-way Catalytic convertor.

Since their inception, the car has been largely supported by the internal combustion engine. Related to the engine combustion process is responsible for releasing hazardous emissions including carbon monoxide (CO), unburned hydrocarbons ( $\mathrm{HC}$ ) and nitrogen oxides (NOx), which has a severe negative effect on humans and the environment. This has led to the development of 
exhaust emission control systems to treat and convert them into less harmful products called catalytic converter [5, 6]. In three decades, automobile manufacturers recognize the need to treat the product of the combustion process that occurs in the internal combustion engine [7]. The initial solution to this challenge is the use of catalytic converter pellets. Pellets are spherical particles with a diameter ranging from $2.5 \mathrm{~mm}$ to $5 \mathrm{~mm}$ and are made of gamma-alumina. Pellets enclosed in a steel shell to form a catalytic converter and laden with precious metals and stabilizers for the treatment of exhaust emissions. The catalytic converter technology has many drawbacks. Due to the design of catalytic converter pellets of this, a large pressure drop occurs across a converter that directly affects the performance of the engine. In addition, a higher risk of losing catalyst for wear particles [ $[\underline{8}, \underline{9}]$. Losses encourage scientists and engineers to develop a monolithic catalytic converter found in today's vehicles. Monolith substrates are the main components of the discharge line after the processing systems found in today's cars. They provide superior performance compared with other types of support pellets. monolith substrate typically characterized by cell density and wall thickness channel them. Because the total surface area of the channels and a small thermal mass of the substrate, the heat transfer is greatly improved, which increases the conversion efficiency indicates improved thermal performance [10]. The thermal performance of the catalytic converter is usually measured in terms of the time required for the catalytic converter to reach the light-off temperature. The " temperature 'light-off was calculated as the temperature at which the conversion efficiency of the pollutant reaches 50\% [11]. Cheng and coauthors suggested many techniques for the mathematical model of the flow field in the substrate ranging from a $1 \mathrm{D}$ model of unidirectional to a full and comprehensive 3D model [12-14]. In their study, CFD (Computational Fluid Dynamics) analysis was used to predict the behavior of the flow, and thermal characteristics of the monolith substrate conversion efficiency. In addition, Young and coresearchers [15-17] developed a mathematical model of the earliest to study the physical and chemical processes in catalytic converters. Their model included the effects of heat and mass transfer in laminar flow in the monolith and the monolith channels. Many researchers investigate and steady state flow simulation under conditions of reacting flows [18-20] and other researchers investigating the flow steady-state non-reacted in a catalytic converter [21, 22]. Transient flow simulation is also used by some researchers to investigate the performance of catalytic converter during the cold-start period including [23-25]. In addition, other researchers studied only flow in the hydraulic behavior of the monolithic substrate under cold flow conditions stable state [26, 27]. According to Shelef and co-authors [28, 29] reviewed the catalytic converter system to control automobile emissions. Their study covered the main principles and the performance of catalytic converters. They discussed the catalytic converter durability and performance of catalytic converters influence on the thermal management of the engine. A more uniform flow distribution increases conversion efficiency and durability of the catalytic converter [11, 30-32]. This leads to less greenhouse gas emissions (Green House Gas) [33, 34]. On the other hand, the study included, Shuai and Wang [35], Chen and Schirmer [36] and Cho et al. [37] focused on the effect of the monolith exhaust manifold design and distribution properties on the flow and hydraulic performance of the catalytic converter. Lai et al. [38] studied the effect of the geometry of the exhaust manifold inflow distribution pipe bending tends to distort the flow and increase the flow misdistribution. They used 3D simulation incorporating robustness brick into the simulation to obtain an accurate prediction. They concluded that streams are becoming more evenly when the inlet pipe shorter in length and smaller bending angle. In addition, they examined the effects of nature brick concluded that the higher the flow distribution more uniform brick resistance observed flow distribution [23, 30, 33, 39]. Liu et al. [40] conducted an experimental and numerical study on reverse flow catalytic converters for natural gas / diesel dual engine. They concluded that the $\mathrm{CO}$ and $\mathrm{HC}$ conversion efficiency improved for reverse flow catalytic converters for low inlet temperature and light engine load only when the initial temperature of the catalytic converter is quite high. Many researchers have studied the effect of pressure drop in the hydraulic performance of the catalytic converter [26, 27, 41, 42]. They examined the effects of inlet flow conditions, properties and catalytic converter substrate geometry on the pressure reduction utilizing a variety of modelling strategies. In addition, the thermal behavior of the catalytic converter has been studied by many researchers $[11, \underline{25}, \underline{43}, \underline{44}]$. The limits lowered the feasibility study and the more feasible approach is required [45]. It can be concluded that the need for a new catalytic converter technology has continued to grow in order to meet the more stringent standards of global emissions of the vehicle and the increasing demand for environmental protection and rising fuel prices. In view of these, most Ghanaians vehicles are for both commercial and private purpose as a means of transporting goods and providing services. Apart from walking (65.6\%), trotro $(16.0 \%)$ is the most popular means of transport to the market [46]. The percentage of used cars being patronized in Ghana is significantly high because of relatively cheaper duty and importation charges. Used vehicles imported into Ghana come with old catalytic converters that might have exhausted their lifespan. The life span of these catalytic converters cannot be determined because of how they have been used on a particular vehicle. Almost all the malfunction catalytic converters are replaced with home used ones which are cut open and are usually sold in the local market (spare parts dealers) such as Abossey Okai, Accra [47, 48] or Suame Magazine, Kumasi [49, $\underline{50]}$. The extent of damage of the ceramic honeycomb catalyst which is widely used as catalyst support and as particulate, filters for vehicular emission control in a used converter cannot be detected. Most People with faulty catalytic converters on their vehicles are forced to use home-made type converters of different brands whose qualities cannot be guaranteed. They cut open and later weld these parts without considering the design parameters such as the accuracy of the angles formed within the converter and the space between the catalyst and the inner housing.

The purpose of this work is to compare the $\mathrm{HC}$ and $\mathrm{CO}$ emission levels on exhaust gases expelling through an existing home used (imported) car converter, a refurbished catalytic converter with a new honeycomb and two other locally developed (purchased in local market) converters installed on a Kia Sportage LX (2009 model) exhaust system. This study further goes on to study the performance of a home used catalytic converter, refurb damaged catalytic converters by replacing the worn-out catalyst elements with imported (brand new) ceramic honeycomb catalysts 
and also to compare the performance characteristics of the home used catalytic converter of refurbished and two other locally developed converter on Kia Sportage LX exhaust system.

\section{MATERIALS AND METHODS}

\subsection{Design of catalytic converter}

\subsubsection{Fabrication}

Assembly of all sub-components together with a catalyst wash coat filled will make a new catalytic converter that is ready for testing as shown in Fig. 2 and 3.

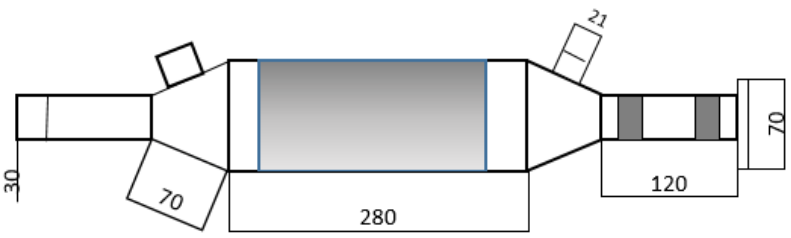

Fig. 2. Assembled Drawing of Catalytic Converter

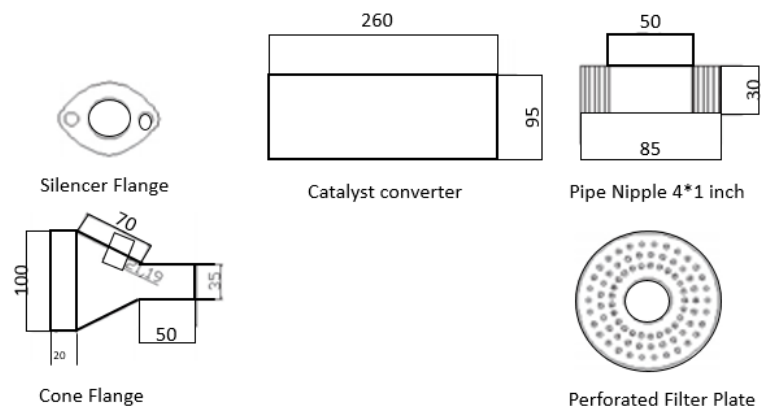

Fig. 3. Detailed Drawing of Catalytic Converter

\subsubsection{Assessment of the Selected Converter}

The starting point of the conversion process is the selection of an old catalytic converter to be converted (refurbished). In this study, four (4) identical old catalytic converters of Kia Sportage (performance characteristics) were obtained from the open market (Abossey Okai and Suame Magazine). Out of these four (4), one was selected for the refurbishment. Figure 4 shows various Catalytic converters of Kia Sportage available in the local market.

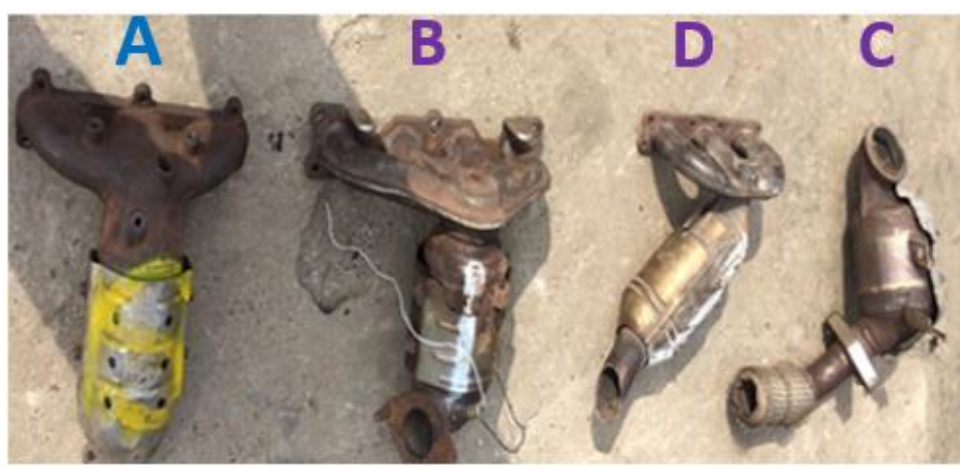

- $\quad$ Fig. 4. Four Old Catalytic Converters

The various converters were assessed and converter ' $A$ ' was selected to enable the selection of appropriate honeycomb for this work. The selection of converter "A" was based on the fact that its exhaust manifold has the same dimensions as the control type.

Table 1 Physical Properties of All Four Catalytic Converters

\begin{tabular}{llllll}
\hline No & Types & $\begin{array}{l}\text { Cell density } \\
\left(\text { cells/in' }{ }^{2}\right)\end{array}$ & $\begin{array}{l}\text { Hydraulic } \\
\text { diameter(mm) }\end{array}$ & $\begin{array}{l}\text { Uncoated wall } \\
\text { thickness }\end{array}$ & $\begin{array}{l}\text { Washcoat } \\
\text { thickness }\end{array}$ \\
\hline A & $\begin{array}{l}\text { Home used } \\
\text { Car' converter unit }\end{array}$ & 400 & 1.14 & 0.15 & 25 \\
B & Refurbished & 400 & 1.14 & 0.15 & 25 \\
$\mathrm{C}$ & $\begin{array}{l}\text { Locally developed 1 } \\
\text { (Suame) }\end{array}$ & 400 & 1.14 & 0.15 & 25 \\
$\mathrm{D}$ & $\begin{array}{l}\text { Locally developed 2 } \\
\text { (Abossey Okai) }\end{array}$ & 400 & 1.14 & 0.15 & 25 \\
\hline
\end{tabular}

Source: Kia Sportage LX Manual Book

The physical properties obtained in the analysis were used to determine other parameters that cannot be obtained experimentally such as geometric surface area, open frontal area and cell pitch.

\subsubsection{Cleaning of residuals in the converter}

A flash cleaning is carried out to remove the residuals in the converter with eco liquid. Eco-Liquid is water-based cleaning and degreases liquid with excellent anti-corrosion properties for parts. The converter was washed thoroughly with a high-pressure water hose. Figure 5 shows the cleaning of the catalytic converter.

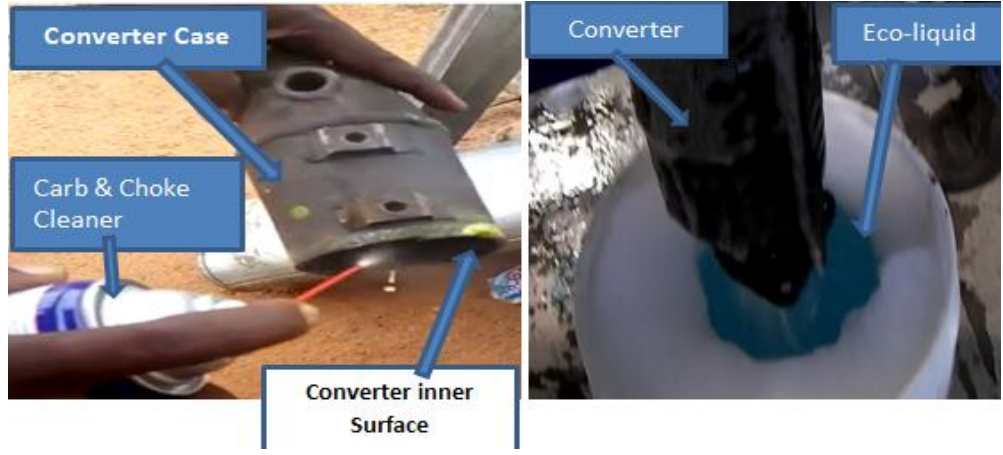

- Fig. 5. Cleaning of residuals in the converter 
To convert the selected home used converter to a refurbished converter, the steel shell is cut open from the top using gas torch of an electric arc welding machine and the honeycomb was removed. The angles and length were all checked to avoid distortion. The brand new imported honeycomb was placed inside the seats. Both the inlet and outlet were also inspected to suit the design of the converter. The system was then put together after thorough checks on the converter to avoid any air space on the walls before fabrication. Figure 3-5 shows the cutting of the catalytic Converter (Refurbished) with an electrical Grinding Machine.

\subsubsection{Gas Welding Process Overview}

Oxygen and acetylene together in a flame provided the heat necessary to melt the metals. This combined with a neutral welding atmosphere and suitable filler material is suitable for heating and cutting purposes. Figure 6 shows a diagram of the Gas welding process of the refurbished converter.

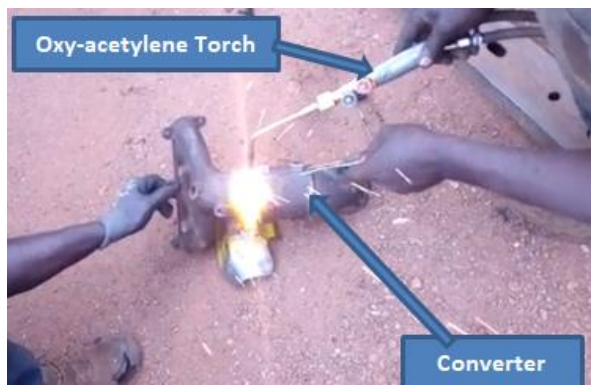

- Fig. 6. Oxy-Acetylene Gas Welding of the Converter

2.2 Installation of the refurbished Catalytic Converter to Exhaust Systems

The last stage of the preparatory process was to join the various catalytic converters to the exhaust system of the Kia Sportage Lx. This was done by directly bolting the refurbished converter to the heads and lead down in the exhaust system with a basic set of hand tools. These processes were repeated for all other converters for the experimental studies. The diameters of the pipes of all the converters were the same for conformity. Figure 3-7 shows the Installation of the Catalytic Converters bolted to the Exhaust Systems of the Kia Sportage LX in the at DVLA-PVTS at Dodowa.

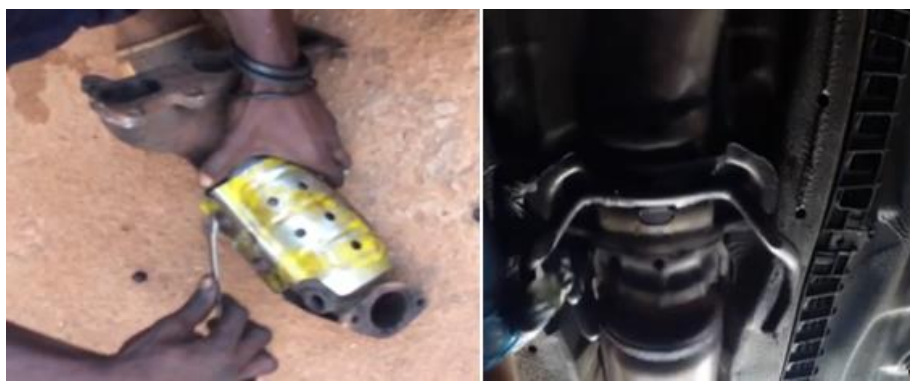

- $\quad$ Fig. 1. Installation of the refurbished Catalytic Converters to Exhaust Systems

\subsection{Exhaust Gas Analyzer}

There are various types of gas analyzers with various guidelines. They are equipped to evaluate various types of gas.
The gas analyzer is the ideal tool to investigate the types of substances present in the sample gas. He acknowledged the species and has the ability to give a good estimate of the number of structures show a numerical or graphical. Depending on the type of examination guidelines opt for gas, can be named both gas chromatography, IR gas analyzer, thermal conductivity gas analyzer, gas analyzer paramagnetic and electrochemical analysis, orsat devices, gravimetric or methanometer gas analyzer. Figure 2-8 shows the smoke gas analyzer. Exhaust emission from the engine was measured with an AVL five gas 444 gas analyzer (Fig. 8).

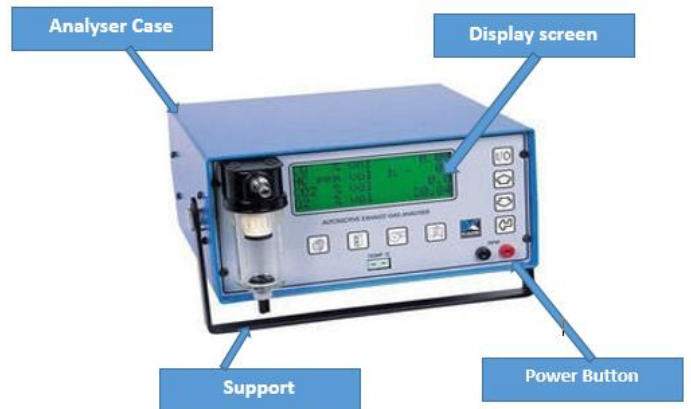

Fig. 8. AVL Gas Analyzer.

2.4 Experimental and Theoretical Formulation (Conceptual framework)

To achieve the specific objectives of this study, a series of experiments carried out at Kia Sportage LX. These can be grouped into four main sections. The first part consists of experiments were conducted to determine the $\mathrm{HC}$ and $\mathrm{CO}$ of the house used Kia Sportage Catalytic Converter. The second part includes the experiments carried out to study the general performance of the type of refurbished with a new honeycomb and finally, the two purchased locally (updated) converter from Suame Magazines and Abossey Okai respectively. The experimental data would be based on the $\mathrm{HC}$ and $\mathrm{CO}$ values of each converter. Figure 9 illustrated the conceptual framework of the study.

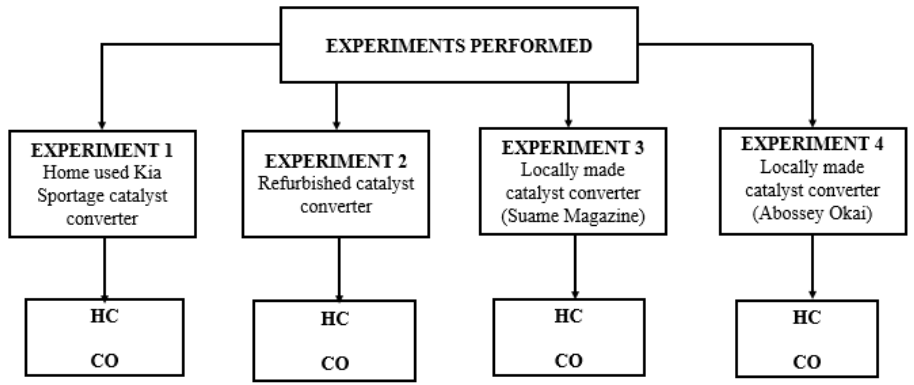

- $\quad$ Fig. 9. Conceptual framework of the study

\subsection{Specifications of the Kia Sportage}

The 2009 Kia Sportage is the ranking is based on its score in 2009 Affordable Compact Sports utility vehicle (SUV) category and it is front-wheel drive. Sportage has a long list of standard interior features. Sportage list of standard features is quite impressive and includes a six-speaker audio system with USB port, air conditioning and satellite radio. features available include a navigation system, leather-wrapped steering wheel and remote 
engine start. Table 3-2 shows some of the specs of the house used

2009 Kia Sportage LX model.

Table 2 Specifications of the Kia Sportage LX

\begin{tabular}{ll}
\hline Specifications of Kia spot age Lx & \\
\hline Car type & Sport utility vehicle \\
Transmission & Automatic \\
Engine type & Petrol \\
Number of Cylinders & Inline 4 \\
Drive Train & Front-wheel Drive \\
\hline
\end{tabular}

\section{RESULTS AND DISCUSSION}

Tests were conducted to determine the effectiveness of catalytic converters used Kia Sportage Lx house, refurbished with brand new honeycomb and two other types of renewable locally installed on a Kia Sportage-house exhaust system is used. The test results of control tests (home-ex converter) compared with the performance of three identical conversational converters and discussion was made on the performance characteristics of the type of converter tested. This section is divided into four main parts as follows:
3.1 Performance Kia Sportage LX Converter Local Converter Compared with three refurbished

This section presents results of experiments conducted to study the performance characteristics of the catalytic converter that already exist on the Kia Sportage, the converter refurbished with brand new honeycomb and two converters purchased locally in relation to the content of the emissions of hydrocarbons and carbon monoxide them through the exhaust system of the Kia Sportage LX, Table 4-1 presents the results of the test. Four major tests performed on four types of converters. Of emission values, the percentage reduction achieved in each case calculated and presented as shown in Table 4-1.

Table 3 Readings of HC's and CO's values of the four converters and their percentage reductions

\begin{tabular}{|c|c|c|c|c|c|c|c|}
\hline \multirow[b]{3}{*}{ No } & \multicolumn{7}{|c|}{ Result at idling speed } \\
\hline & \multirow{2}{*}{\multicolumn{2}{|c|}{ Converters type }} & \multicolumn{5}{|l|}{ Emissions } \\
\hline & & & $\begin{array}{l}\text { Hydrocarbons } \\
\text { (ppm) }\end{array}$ & $\begin{array}{l}\mathrm{HC} \\
(\%)\end{array}$ & Reduction & $\begin{array}{l}\text { Carbon Monoxide } \\
(\% \mathrm{Vol})\end{array}$ & $\begin{array}{l}\text { CO Reduction } \\
(\%)\end{array}$ \\
\hline 1 & Home used & & 65.8 & 0 & & 2.37 & 0 \\
\hline 2 & Refurbished & & 61.1 & 7.69 & & 1.68 & 41.07 \\
\hline 3 & $\begin{array}{l}\text { Locally made } \\
\text { Magazine) }\end{array}$ & $1 \quad$ Suame & 63.1 & 4.28 & & 1.79 & 33.15 \\
\hline 4 & Locally made 2 (A & baosokai) & 63.7 & 3.3 & & 1.85 & 28.11 \\
\hline
\end{tabular}

\subsubsection{Emissions (idling)}

Figure 10 shows emission values in the idling case for the test involving the four converter types used for study as presented in table 3. In Figure 10 it can be seen that the level of hydrocarbon released by the refurbished converter is $61.1 \mathrm{ppm}$, which is relatively lower compared with the other converters. The home used converter registered the highest levels of $\mathrm{HC}$ emission with a value of $65.8 \mathrm{ppm}$. Per the results depicted in figure 10, it can be said that the refurbished converter performs much better than the other samples tested. In comparison, the refurbished converter released about $7.69 \%$ of $\mathrm{HC}$ emissions less than the home-used type. However, it can be observed that the emissions recorded for all samples tested are much lower than the standard value of 200 ppm.

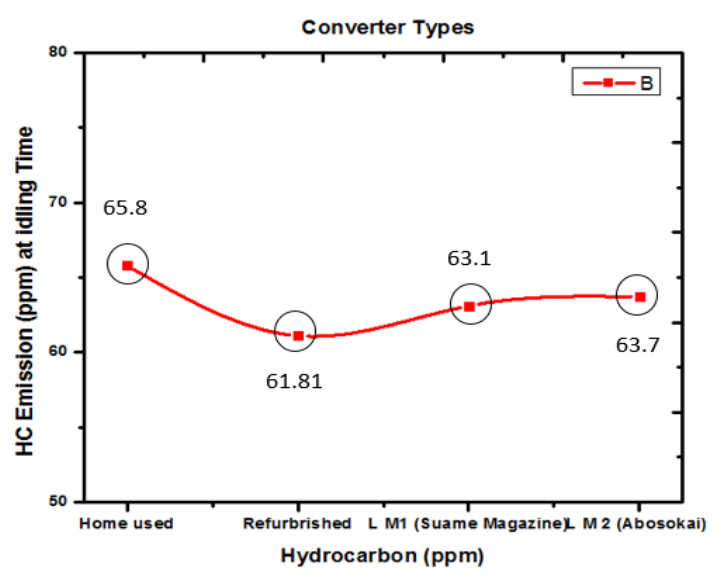

- Fig. 10. Comparison of HC Values for types of Converters 
Figure 11 shows emission values in the idling case for the test involving the four converter types used for study as presented in table 3. According to figure 11, it can be observed that the refurbished converter recorded the lowest $\mathrm{CO}$ emission levels of $1.68 \%$ Vol followed by the locally developed type 1 . The home home-used type recorded the highest value of $2.37 \% \mathrm{Vol}$. in comparison with the standard recommended value, however, it can be seen that the $\mathrm{CO}$ emission values for all samples tested fall far above the mark of $0.2 \% \mathrm{Vol}$. CO.

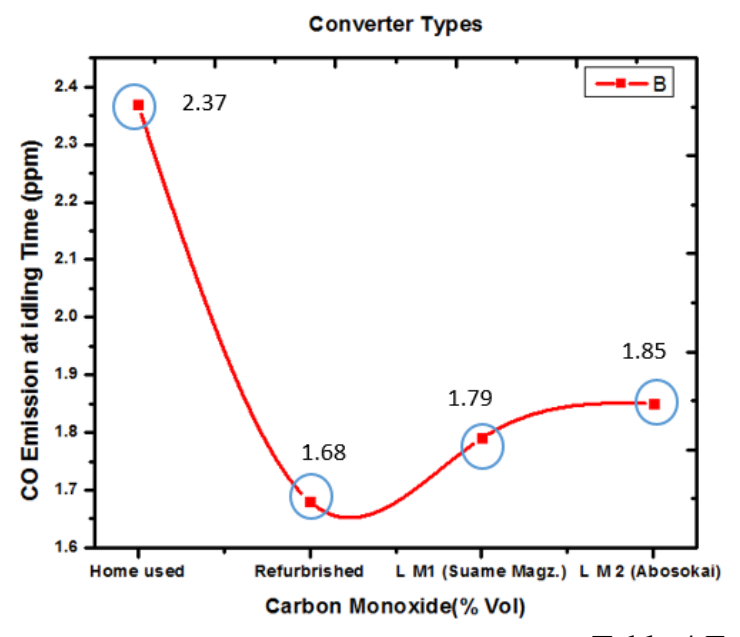

Table 4 Emissions recorded at varying speeds

\section{- Fig. 11. Comparison between of $\mathrm{CO}$ of Various Converters}

\subsubsection{Emission Reduction}

The refurbished converter achieved the highest emission reduction of about $7.69 \% \mathrm{HC}$ and $41.07 \% \mathrm{CO}$ in comparison with the other samples tested. Thus, the refurbished converter can be said to be the most effective sample in this regard.

\section{2 $\mathrm{HC}$ and $\mathrm{CO}$ emissions with the Engine Speed}

$\mathrm{HC}$ and $\mathrm{CO}$ emission measurements were also done at varying speeds in order to determine the effect of speed on emissions. For safety reasons, the speed of the vehicle for the test was run from $10.0 \mathrm{~km} / \mathrm{hr}$ to $60.0 \mathrm{~km} / \mathrm{hr}$ at 5.0 seconds intervals for the entire period of 30 minutes. Table 4 shows emission values of the converters types from four sets of tests when the vehicle was run from an initial speed of $10.0 \mathrm{~km} / \mathrm{hr}$ to 60 $\mathrm{km} / \mathrm{hr}$ on rollers at DVLA - Ghana.

\begin{tabular}{|c|c|c|c|c|c|c|c|c|c|}
\hline \multirow[b]{3}{*}{ 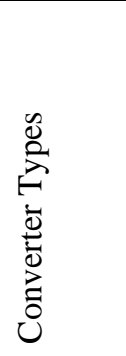 } & \multirow{3}{*}{$\begin{array}{l}\begin{array}{l}\text { Selected } \\
\text { converters }\end{array} \\
\text { Emission } \\
\text { Types }\end{array}$} & \multicolumn{8}{|c|}{ EMISSIONS } \\
\hline & & \multicolumn{2}{|c|}{ Home used } & \multicolumn{2}{|c|}{ Refurbished } & \multicolumn{2}{|c|}{$\begin{array}{l}\text { Locally made } 1 \\
\text { (Suame Magazine) }\end{array}$} & \multicolumn{2}{|c|}{$\begin{array}{l}\text { Locally made } \\
\text { (Abaosokai) }\end{array}$} \\
\hline & & $\begin{array}{l}\mathrm{HC} \\
(\mathrm{ppm}) \\
\text { Home } \\
\text { Used }\end{array}$ & $\begin{array}{l}\mathrm{CO}(\% \\
\text { Vol }) \\
\text { Home } \\
\text { Used }\end{array}$ & $\begin{array}{l}\mathrm{HC}(\mathrm{ppm}) \\
\text { Refurbish } \\
\text { ed }\end{array}$ & $\begin{array}{l}\mathrm{CO} \quad(\% \\
\text { Vol }) \\
\text { Refurbish } \\
\text { ed }\end{array}$ & $\begin{array}{l}\mathrm{HC} \\
(\mathrm{ppm}) \\
\text { Locally } \\
\text { Develop } \\
\text { ed 1 } \\
\end{array}$ & $\begin{array}{l}\mathrm{CO} \quad(\% \\
\text { Vol }) \\
\text { Develop } \\
\text { ed 1 }\end{array}$ & 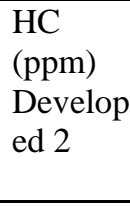 & $\begin{array}{l}\mathrm{CO} \quad(\% \\
\text { Vol }) \\
\text { Develop } \\
\text { ed } 2\end{array}$ \\
\hline & 10 & 65.8 & 2.37 & 60 & 2.36 & 60 & 2.38 & 61 & 2.37 \\
\hline & 20 & 65.9 & 2.38 & 60.2 & 2.36 & 60.21 & 2.37 & 61.2 & 2.27 \\
\hline & 30 & 70.1 & 2.38 & 60.2 & 2.37 & 61.1 & 2.38 & 61.9 & 2.38 \\
\hline$\sum^{z}$ & 40 & 70.2 & 2.4 & 61 & 2.38 & 61.2 & 2.39 & 62.2 & 2.39 \\
\hline$\ddot{z}$ & 50 & 70.6 & 2.5 & 62 & 2.41 & 62.3 & 2.41 & 62.3 & 2.42 \\
\hline$\frac{\varpi}{n}$ & 60 & 70.9 & 2.52 & 63 & 2.41 & 63.2 & 2.42 & 63.1 & 2.42 \\
\hline $\begin{array}{l}\text { Av } \\
\text { Emissio } \\
\mathrm{ns}\end{array}$ & 35 & $\begin{array}{l}68.91 \\
6667\end{array}$ & 2.425 & 61.06667 & 2.3816667 & 61.335 & $\begin{array}{l}2.391666 \\
667\end{array}$ & 61.95 & $\begin{array}{l}2.391833 \\
333\end{array}$ \\
\hline
\end{tabular}

3.2.1 Variations of HC Emissions versus Engine Speeds

Figure 12 shows a graph of $H C$ emissions with respect to engine speed. It can be observed that (see table 4-2) the HC emissions increase with increasing speed. Results show that the HC emission rises from $65.8 \mathrm{ppm}$ at a speed of $10.0 \mathrm{~km} / \mathrm{hr}$ to a value of $70.9 \mathrm{ppm}$ at a speed of $60.0 \mathrm{~km} / \mathrm{hr}$. The average speed was $35.0 \mathrm{~km} / \mathrm{hr}$ with a recorded average emission value of 70.8 ppm. 


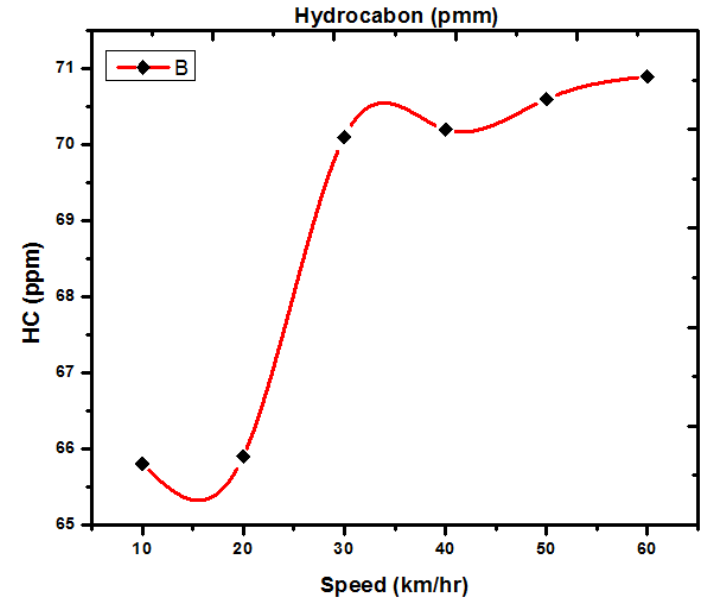

- Fig. 12. Graph of HC emission vs Engine Speed

\subsubsection{Variation of $\mathrm{CO}$ emissions with Engine Speed}

Figure 13 shows that $\mathrm{CO}$ emission of the home-used converter varies linearly with engine speed. As indicated in figure 13 , it is observed that the $\mathrm{CO}$ emissions increase with increasing engine speed. The results show that the $\mathrm{CO}$ emission rises from $2.37 \% \mathrm{Vol}$ at a speed of $10.0 \mathrm{~km} / \mathrm{hr}$ to a value of $2.52 \% \mathrm{Vol}$ at a speed of $60.0 \mathrm{~km} / \mathrm{hr}$. At an average speed of $35.0 \mathrm{~km} / \mathrm{hr}$ the CO emission recorded was $2.39 \%$ Vol.

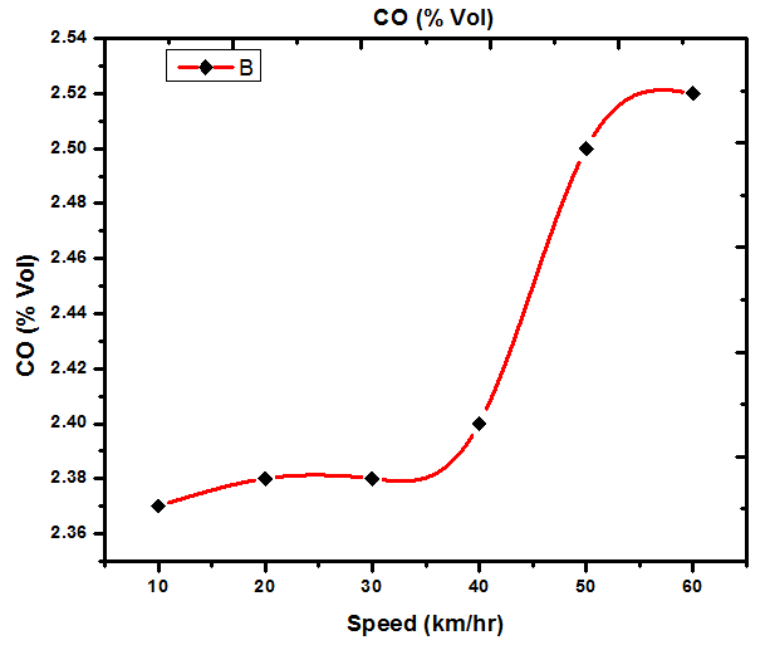

- Fig.13. CO (\% Vol) vs Speed $(\mathrm{km} / \mathrm{hr})$

3.3 Emissions results of Home-used converter and Refurbished converter

Figure 14 shows that the $\mathrm{HC}$ emitted from the refurbished converter exhaust system at a speed of $10.0 \mathrm{~km} / \mathrm{hr}$ was $60.0 \mathrm{ppm}$ which is relatively lower than that of the home used $(65.8 \mathrm{ppm})$ catalytic converter. This implies that there is a significant improvement in reduction (5.8 $\mathrm{ppm}$ ) of $\mathrm{HC}$ emission present in the exhaust gas. Figure 4-5 indicates that, at the highest speed of $60 \mathrm{~km} / \mathrm{hr}$, HC emissions of the Home-used and refurbished converters were $70.9 \mathrm{ppm}$ and $63.0 \mathrm{ppm}$ respectively. Figure 14 shows a graph of $\mathrm{HC}$ versus speed for home used and refurbished converters.

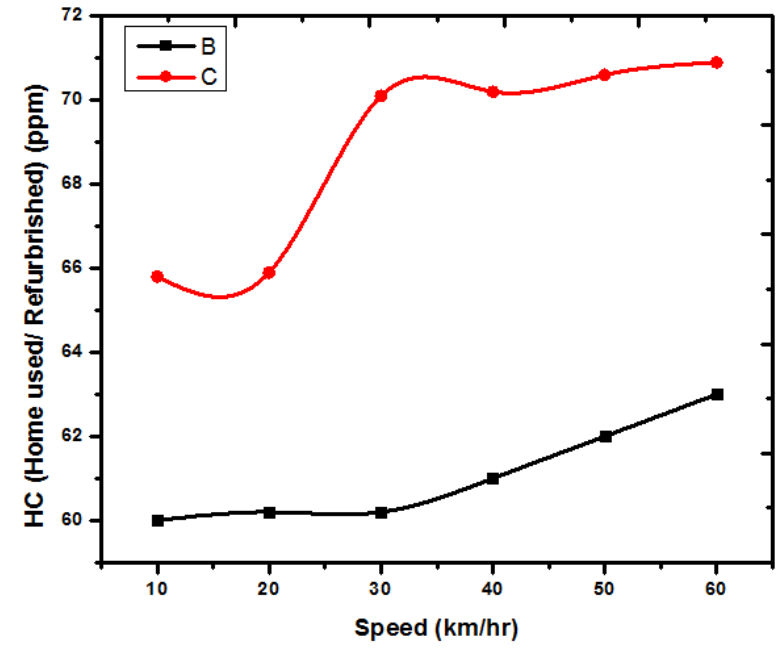

\section{- Fig. 14. HC Emissions of Home Used Converter} versus Refurbished Converter

At the same time, there is a significant reduction of $0.01 \% \mathrm{Vol}$ in the $\mathrm{CO}$ emission between the home-used converter and the refurbished. Over the speed range of $10-60 \mathrm{~km} / \mathrm{hr}$, the CO emission recorded for refurbished and home-used converters were $2.52 \% \mathrm{Vol}$ and $2.41 \% \mathrm{Vol}$ respectively. In other words, the refurbished catalytic converter was able to reduce the HC emissions by $12.54 \%$ and $\mathrm{CO}$ emissions by $4.56 \%$. Figure 15 shows a graph of $\mathrm{CO}$ versus speed for home used and refurbished converters. It can be observed that as speed increases \% Vol of CO emission for refurbished converter increases from 2.36 to $2.41 \%$ Vol. whereas the $\mathrm{CO}$ emissions for the home-used type remains fairly constant. It can also be observed that $\mathrm{HC}$ emission level of the refurbished type remains constant with increasing speed whereas that of the home-used converter varies between 60 and 63 ppm.

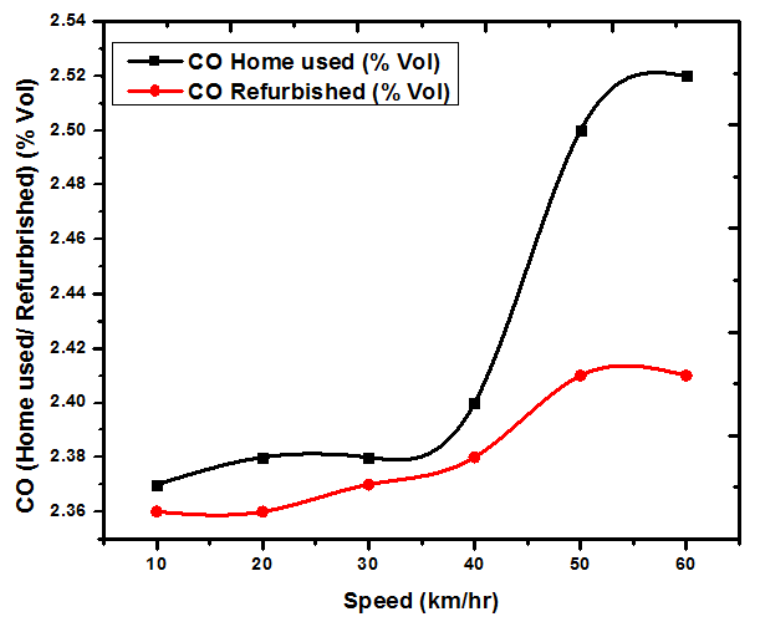

- Fig. 15. CO Emissions of Home Used Converter versus Refurbished Converter

3.4 Comparison of $\boldsymbol{H C}$ and $\boldsymbol{C O}$ Emissions of Refurbished and Locally Developed Converters

3.4.1 Comparison of $\boldsymbol{H C}$ Emissions of refurbished and locally developed Converters 
By comparing the $H C$ emissions of the refurbished and locally developed converters, it can be stated that the difference in $\mathrm{HC}$ values are significantly high. The differences in $\mathrm{HC}$ emission values were obtained from table 4 . The refurbished converter had an average $\mathrm{HC}$ emission of $61.067 \mathrm{ppm}$ as compared to the converters from Suame magazine (Locally Developed 1) and Abossey Okai (Locally Developed 2) which had average HC emission values of $61.335 \mathrm{ppm}$ and $61.950 \mathrm{ppm}$ at an average speed of $35 \mathrm{~km} / \mathrm{hr}$ respectively. According to figure 16, it can be observed that the refurbished converter had the lowest $\mathrm{HC}$ emissions making it the most effective among the three converters. It can also be seen that the developed converter from Abossey Okai had the highest $\mathrm{HC}$ emission. Considering idling condition from table 4-1, the percentage reduction of the $\mathrm{HC}$ emissions of the refurbished and the two locally developed converters were also calculated. This gives the percentage emission reduction value of the refurbished converter as $7.69 \%$ whilst the Suame Magazine and Abossey Okai converters recorded $4.28 \%$ and $3.3 \%$ respectively. Again, there was a significant improvement in the percentage reduction of $\mathrm{HC}$ emission when compared to the Locally Developed converter bought from Abossey Okai. From the percentage reductions, it can be observed that there was an improvement in the $\mathrm{HC}$ emissions for the refurbished converter as compared to the other converters when the vehicle was idling.

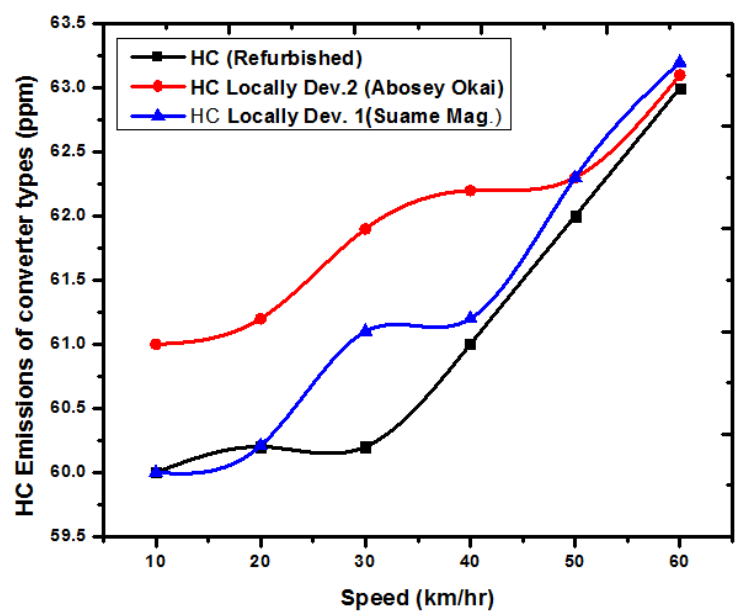

\section{- $\quad$ Fig. 16. Comparison of $H C$ Emissions of refurbished and locally developed Converters}

\subsubsection{Comparison of $\boldsymbol{C O}$ Emissions, refurbished and locally} developed Converters

Similarly, the $\mathrm{CO}$ emissions of the three converters were also considered during the experiment. It was also observed that the refurbished converter had a lower average $\mathrm{CO}$ emission of 2.381 $\%$ Vol as compared to the locally developed converter 1 (2.391 $\%$ Vol) and locally developed converter 2 (2.391 \%Vol) respectively. In figure 17 , it can be observed that the refurbished converter achieves a better performance with respect to $\mathrm{CO}$ emissions since it recorded to the lowest value of $1.68 \% \mathrm{Vol}$. for the scenario involving idling speed. However, the values of $\mathrm{CO}$ recorded for all samples were far higher than the recommended value of $0.2 \% \mathrm{Vol}$. Hence it is advised that a brand new honeycomb should be considered since that works better with $\mathrm{CO}$ emission and also have a longer lifespan.

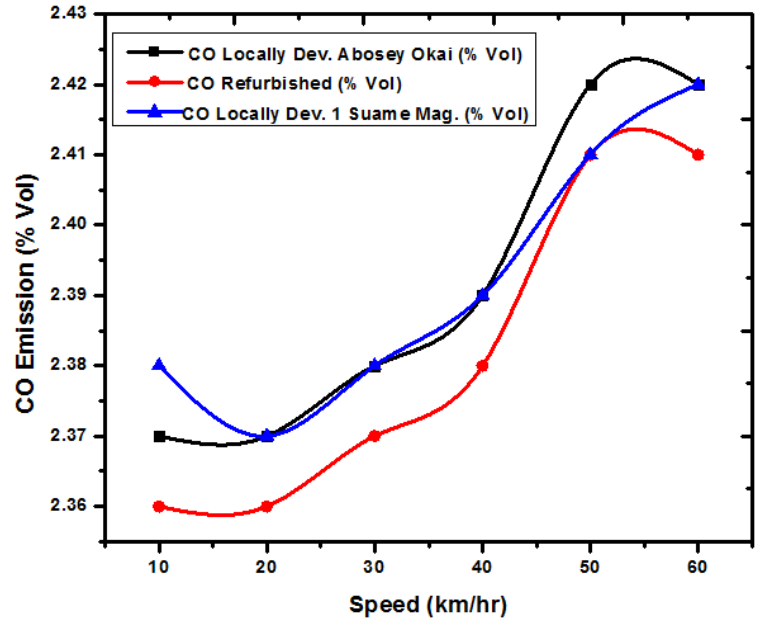

- Fig. 17. Comparison of $C O$ Emissions of refurbished
and locally developed Converters

\section{CONCLUSIONS AND RECOMMENDATIONS}

\subsection{Conclusion}

This study examined the catalytic converter performance of $\mathrm{HC}$ and $\mathrm{CO}$ emission for home used Kia Sportage LX's catalytic converter, a refurbished type and the performance of two locally developed types from the local market installed on the home used Kia Sportage exhaust system.

From the results of the study, the following conclusions are made:

1. The refurbished catalytic converter with welded test and eco-liquid wash, produced lower emission than the home used, locally developed converter 1 (Suame Magazine) and locally developed converter 2 (Abossey Okai). For the locally made ones, the welded part of the case was not uniform therefore creating space for the exhaust gas to escape without proper filtration.

2. An HC emission of $60.0 \mathrm{ppm}$ was recorded for the refurbished converter at an initial speed of $10.0 \mathrm{~km} / \mathrm{hr}$ which is relatively lower than the $\mathrm{HC}$ emission recorded for the home used (65.8 ppm) catalytic converter. Results further show that the refurbished type achieves a significant $H C$ emission reduction of $5.8 \mathrm{ppm}$ when compared with the other types. For $\mathrm{CO}$ emission, the refurbished type had a reduction of $0.01 \% \mathrm{Vol}$ when compare with the home-used converter at varying speeds.

3. At the upper speed of $60.0 \mathrm{~km} / \mathrm{hr}$, both the home-used and refurbished converter recorded the maximum $\mathrm{HC}$ emission values of $70.9 \mathrm{ppm}$ and $63.0 \mathrm{ppm}$ respectively, whereas the corresponding maximum $\mathrm{CO}$ emission values recorded were $2.52 \% \mathrm{Vol}$ for the home used type and $2.42 \% \mathrm{Vol}$. for the refurbished type.

4. At the upper speed of $60.0 \mathrm{~km} / \mathrm{hr}$, the refurbished converter reduces its $\mathrm{HC}$ emission by $12.54 \%$ and $\mathrm{CO}$ emissions by $4.56 \%$ compared with the home-used converter. On the other hand, at the upper speed of 60.0 $\mathrm{km} / \mathrm{hr}$, local type 1 and local type 2 reduce $\mathrm{HC}$ emission by $12.18 \%$ and $12.36 \%$ respectively whereas the corresponding reduction values for $\mathrm{CO}$ emission was $4.13 \%$ for both local types 
5. At the maximum test speed of $60 \mathrm{~km} / \mathrm{hr}$ both the homeused and refurbished converters recorded the highest amount of $H C(70.9 \mathrm{ppm}, 63 \mathrm{ppm})$ and $C O(2.52 \% \mathrm{Vol}$, $2.42 \% \mathrm{Vol})$ from the engine exhaust respectively.

6. The refurbished converter yielded about $3.41 \%$ reduction in $\mathrm{HC}$ emission and $7.92 \% \mathrm{CO}$ emission which is better as compared to the Locally Developed converter 1 (Magazine). Again, the refurbished converter attained $4.39 \%$ reduction in $\mathrm{HC}$ emission when compared to the Locally Developed converter 2 (Abossey Okai) at idling speed.

5.2 Recommendations

In respect to the results obtained, the following recommendations are made:

- further work should be carried out to compare the performance of the four converters for the recommended maximum speed limit on the high way in Ghana (being $100 \mathrm{~km} / \mathrm{hr}$ )

- In terms of HC performance, the refurbished type is recommended since it produced the lowest $\mathrm{HC}$ emissions, which falls far below the international standard. However, all samples tested could not meet international standards for $\mathrm{CO}$ emissions. Hence, it is recommended that the DVLA should enforce existing regulations by ensuring that all converters used on registered vehicles should be brand new.

\section{REFERENCES}

[1] [1] S. Koutros, M. Kogevinas, M. C. Friesen, P. A. Stewart, D. Baris, M. R. Karagas, et al., "Diesel exhaust and bladder cancer risk by pathologic stage and grade subtypes," Environment International, vol. 135, p. 105346, 2020/02/01/ 2020 .

[2] [2] J. M. Ferguson, S. Costello, H. Elser, A. M. Neophytou, S. Picciotto, D. T. Silverman, et al., "Chronic obstructive pulmonary disease mortality: The Diesel Exhaust in Miners Study (DEMS)," Environmental Research, vol. 180, p. 108876, 2020/01/01/ 2020.

[3] [3] A. Vembathu Rajesh, C. Mathalai Sundaram, V. Sivaganesan, B. Nagarajan, and S. Harikishore, "Emission reduction techniques in CI engine with catalytic converter," Materials Today: Proceedings, 2019/08/21/ 2019.

[4] [4] X. Wang, Y. Wang, Y. Bai, P. Wang, D. Wang, and F. Guo, "Effects of 2,5-dimethylfuran addition on morphology, nanostructure and oxidation reactivity of diesel exhaust particles," Fuel, vol. 253, pp. 731-740, 2019/10/01/ 2019.

[5] [5] S. Chan and D. Hoang, "Heat transfer and chemical reactions in exhaust system of a cold-start engine," International journal of heat and mass transfer, vol. 42, pp. 4165-4183, 1999.

[6] [6] C. Bruno, P. Walsh, D. Santavicca, and F. Bracco, "High temperature catalytic combustion of $\mathrm{CO}-\mathrm{O} 2-\mathrm{N} 2, \mathrm{Ar}, \mathrm{He}, \mathrm{CO} 2-\mathrm{H} 2 \mathrm{O}$ mixtures of platinum," International Journal of Heat and Mass Transfer, vol. 26, pp. 1109-1120, 1983.

[7] [7] R. J. Farrauto and R. M. Heck, "Catalytic converters: state of the art and perspectives," Catalysis Today, vol. 51, pp. 351-360, 1999.

[8] [8] C. Wassermayr, W. Brandstätter, and P. Prenninger, "An integrated approach for the design of diesel engine exhaust systems to meet Euro 4 and beyond emissions legislations," in Thermo-and Fluid Dynamic Processes in Diesel Engines 2, ed: Springer, 2004, pp. 235-254.

[9] [9] M. L. Sattler, "Technologies for reducing NOx emissions from nonroad diesel vehicles: An Overview," White paper, published in EM a publication of the Air \& Waste Management Association for Environmental Managers, pp. 20-29, 2002.

[10] [10] Y.-D. Kim, W.-S. Kim, and Y. Lee, "Influences of exhaust gas temperature and flow rate on optimal catalyst activity profiles," International Journal of Heat and Mass Transfer, vol. 85, pp. 841-851, 2015.
[11] [11] S.-J. Jeong and W.-S. Kim, "Three-dimensional numerical study on the use of warm-up catalyst to improve light-off performance," SAE Technical Paper 0148-7191, 2000.

[12] [12] J. Chen, H. Yang, N. Wang, Z. Ring, and T. Dabros, "Mathematical modeling of monolith catalysts and reactors for gas phase reactions," Applied Catalysis A: General, vol. 345, pp. 1-11, 2008.

[13] [13] C. Ozhan, D. Fuster, and P. Da Costa, "Multi-scale flow simulation of automotive catalytic converters," Chemical Engineering Science, vol. 116, pp. 161-171, 2014.

[14] [14] A. Kumar and S. Mazumder, "Toward simulation of full-scale monolithic catalytic converters with complex heterogeneous chemistry," Computers \& chemical engineering, vol. 34, pp. 135-145, 2010.

[15] [15] L. C. YOUNG and B. A. FINLAYSON, "Mathematical modeling of the monolith converter," ed: ACS Publications, 1974

[16] [16] N. B. Ferguson and B. A. Finlayson, "Transient modeling of a catalytic converter to reduce nitric oxide in automobile exhaust," AIChE Journal, vol. 20, pp. 539-550, 1974.

[17] [17] R. H. Heck, J. Wei, and J. R. Katzer, "Mathematical modeling of monolithic catalysts," AIChE Journal, vol. 22, pp. 477-484, 1976.

[18] [18] W. Taylor, "CFD prediction and experimental validation of hightemperature thermal behavior in catalytic converters," SAE Technical Paper 0148-7191, 1999.

[19] [19] H. Santos and M. Costa, "Analysis of the mass transfer controlled regime in automotive catalytic converters," International journal of heat and mass transfer, vol. 51, pp. 41-51, 2008.

[20] [20] G. Groppi and E. Tronconi, "Theoretical analysis of mass and heat transfer in monolith catalysts with triangular channels," Chemical engineering science, vol. 52, pp. 3521-3526, 1997.

[21] [21] A. Holmgren, T. Grönstedt, and B. Andersson, "Improved flow distribution in automotive monolithic converters," Reaction Kinetics and Catalysis Letters, vol. 60, pp. 363-371, 1997.

[22] [22] M.-C. Lai, J.-Y. Kim, C.-Y. Cheng, P. Li, G. Chui, and J. Pakko, "Three-dimensional simulations of automotive catalytic converter internal flow," SAE transactions, pp. 241-250, 1991.

[23] [23] K. Ramanathan, V. Balakotaiah, and D. H. West, "Light-off criterion and transient analysis of catalytic monoliths," Chemical Engineering Science, vol. 58, pp. 1381-1405, 2003.

[24] [24] J. Braun, T. Hauber, H. Többen, J. Windmann, P. Zacke, D. Chatterjee, et al., "Three-dimensional simulation of the transient behavior of a three-way catalytic converter," SAE Technical Paper 0148-7191, 2002.

[25] [25] V. Chakravarthy, J. Conklin, C. Daw, and E. D’Azevedo, "Multidimensional simulations of cold-start transients in a catalytic converter under steady inflow conditions," Applied Catalysis A: General, vol. 241, pp. 289306, 2003.

[26] [26] R. Hayes, A. Fadic, J. Mmbaga, and A. Najafi, "CFD modelling of the automotive catalytic converter," Catalysis today, vol. 188, pp. 94-105, 2012.

[27] [27] S. F. Benjamin, Z. Liu, and C. A. Roberts, "Automotive catalyst design for uniform conversion efficiency," Applied Mathematical Modelling, vol. 28, pp. 559-572, 2004.

[28] [28] M. Shelef and R. W. McCabe, "Twenty-five years after introduction of automotive catalysts: what next?," Catalysis today, vol. 62, pp. 35-50, 2000.

[29] [29] G. C. Koltsakis and A. M. Stamatelos, "Catalytic automotive exhaust aftertreatment," Progress in Energy and Combustion Science, vol. 23, pp. 139, 1997.

[30] [30] E. Karvounis and D. N. Assanis, "The effect of inlet flow distribution on catalytic conversion efficiency," International journal of heat and mass transfer, vol. 36, pp. 1495-1504, 1993.

[31] [31] A. Martin, N. Will, A. Bordet, P. Cornet, C. Gondoin, and X. Mouton, "Effect of flow distribution on emissions performance of catalytic converters," SAE transactions, pp. 384-390, 1998.

[32] [32] G. Bella, V. Rocco, and M. Maggiore, "A study of inlet flow distortion effects on automotive catalytic converters," 1991.

[33] [33] S. H. Amirnordin, S. M. Seri, W. Salim, H. A. Rahman, and K. Hasnan, "Pressure drop analysis of square and hexagonal cells and its effects on the performance of catalytic converters," International Journal of Environmental Science and Development, vol. 2, pp. 239-247, 2011.

[34] [34] F. Ekström and B. Andersson, "Pressure drop of monolithic catalytic converters experiments and modeling," SAE Transactions, pp. 425-433, 2002. 
[35] [35] S.-J. Shuai and J.-X. Wang, "Unsteady temperature fields of monoliths in catalytic converters," Chemical Engineering Journal, vol. 100, pp. 95-107, 2004.

[36] [36] M. Chen and K. Schirmer, "A modelling approach to the design optimization of catalytic converters of IC engines," in ASME 2003 Internal Combustion Engine and Rail Transportation Divisions Fall Technical Conference, 2003, pp. 201-207.

[37] [37] Y.-S. Cho, D.-S. Kim, M. Han, Y. Joo, J.-H. Lee, and K.-D. Min, "Flow distribution in a close-coupled catalytic converter," SAE transactions, pp. 1343-1349, 1998.

[38] [38] M.-C. Lai, T. Lee, J.-Y. Kim, C.-Y. Cheng, P. Li, and G. Chui, "Numerical and experimental characterizations of automotive catalytic converter internal flows," Journal of Fluids and Structures, vol. 6, pp. 451470, 1992.

[39] [39] H. Weltens, H. Bressler, F. Terres, H. Neumaier, and D. Rammoser, "Optimisation of catalytic converter gas flow distribution by CFD prediction," SAE Technical Paper 0148-7191, 1993.

[40] [40] B. Liu, R. Hayes, Y. Yi, J. Mmbaga, M. Checkel, and M. Zheng, "Three dimensional modelling of methane ignition in a reverse flow catalytic converter," Computers \& chemical engineering, vol. 31, pp. 292-306, 2007.

[41] [41] G. Agrawal, N. S. Kaisare, S. Pushpavanam, and K. Ramanathan, "Modeling the effect of flow mal-distribution on the performance of a catalytic converter," Chemical engineering science, vol. 71, pp. 310-320, 2012.

[42] [42] H. Bressler, D. Rammoser, H. Neumaier, and F. Terres, "Experimental and predictive Investigation of a close coupled catalyst converter with pulsating flow," SAE transactions, pp. 255-267, 1996.

[43] [43] T. Shamim, H. Shen, S. Sengupta, S. Son, and A. Adamczyk, "A comprehensive model to predict three-way catalytic converter performance," J. Eng. Gas Turbines Power, vol. 124, pp. 421-428, 2002.

[44] [44] C.-M. Chung, C.-C. Chen, W.-P. Shih, T.-E. Lin, R.-J. Yeh, and I. Wang, "Automated machine learning for Internet of Things," in 2017 IEEE International Conference on Consumer Electronics-Taiwan (ICCE-TW), 2017, pp. 295-296.

[45] [45] J. von Rickenbach, F. Lucci, C. Narayanan, P. D. Eggenschwiler, and D. Poulikakos, "Multi-scale modelling of mass transfer limited heterogeneous reactions in open cell foams," International Journal of Heat and Mass Transfer, vol. 75, pp. 337-346, 2014.

[46] [46] K. A. McNitt, K. Parimal, A. I. Share, A. C. Fahrenbach, E. H. Witlicki, M. Pink, et al., "Reduction of a redox-active ligand drives switching in a $\mathrm{Cu}$ (I) pseudorotaxane by a bimolecular mechanism," Journal of the American Chemical Society, vol. 131, pp. 1305-1313, 2009.

[47] [47] V. Okoye, J. Sands, and C. A. Debrah, "The Accra pilot Bus-Rapid Transit project: Transport-land use research study," Millennium Cities Initiative and Accra Metropolitan Assembly, The Earth Institute at Columbia
University, New York. URI: http://mci. ei. columbia. edu/files/2013/03/Transport-Land-Use-Research-Study. pdf, 2010.

[48] [48] P. Y. G. Owusu, "Youth Entrepreneurship in Auto Spare Parts Sales and Repair Service in Accra, Ghana."

[49] [49] S. Amedorme and K. Agbezudor, "Investigation of vehicle alterations and modifications at Suame Magazine in Kumasi, Ghana," Int. J. Mech. Eng. Res. Appl, vol. 1, pp. 48-53, 2013.

[50] [50] T. Jaarsma, H. Maat, P. Richards, and A. Wals, "The role of materiality in apprenticeships: the case of the Suame Magazine, Kumasi, Ghana," Journal of Vocational Education \& Training, vol. 63, pp. 439-449, 2011.

\section{AUTHORS}

First Author - Isaac Tekper, Dept. of Mechanical Engineering, Kumasi Technical University, Kumasi, 00233, Ghana

Second Author - Joseph Kwame Lewballah, Dept. of Mechanical Engineering, Kumasi Technical University, Kumasi, 00233, Ghana

Third Author - James Kwasi Quaisie, School of Mechanical Engineering, Jiangsu University, Zhenjiang, Jiangsu 212013, China

Fourth Author - Fred Joseph Komla Adzabe, Dept. of Mechanical Engineering, Kumasi Technical University, Kumasi, 00233, Ghana

Fifth Author - Emmanuel Yeboah Osei, Dept. of Mechanical Engineering, Kumasi Technical University, Kumasi, 00233, Ghana

Sixth Author - Emmanuel Asamoah, School of Mechanical Engineering, Jiangsu University, Zhenjiang, Jiangsu 212013, China

Seventh Author - Philip Baidoo, Faculty of Technology, University of Education Winneba, Kumasi, 00233, Ghana Eight Author - Andrews Danquah, Dept. of Mechanical Engineering, Kumasi Technical University, Kumasi, 00233, Ghana 